\title{
Beyond All Reason: Spaces of Hope in the Struggle for England's Universities
}

\author{
Cold Awakenings: The Coming \\ of Private Education in \\ a Winter of Discontent
}

ENGLAND's PUBlic UNIVERSITY SYSTEM HAS been groaning and lurching toward privatization for decades. Until recently, however, it was still possible to argue that "the attempt to close off and render impossible the experience of education as a collaborative pursuit of a public good and to make possible its full commodification has not yet wholly succeeded" here. ${ }^{1}$ Despite being deeply disillusioned with increasingly neoliberal forms of academic work, many academics have thus also maintained that these could never be totalizing; that their implementation could be mediated through critical professional practice, and that social-democratic justifications for public higher education could prevail even within discourses that had become inhospitable to the very idea of the public itself.

In the autumn of 2010, however, these guarded spaces of hope collapsed in an acute atmosphere of crisis when Britain's new conservative-liberal coalition government confirmed the details of its "radical plan to shake up higher education." 2 Far from just another shift in a long succession of policy reforms, the proposals are designed to structurally transform higher education from a public, cultural good into what Stefan Collini has called a "lightly regulated market

\footnotetext{
A B S T R A C T This essay examines how academics and students in England have been primed to comply with a political agenda of "deep" neoliberalization through cumulative processes of institutional and subjective undermining and considers what might be an appropriate logic of critical response. It first describes how the embedding of principles and mechanisms of market governance within academic life has depoliticized methods for critically theorizing and collectively resisting these processes and then explores the work of recent student-led opposition to the British government's new policies, teasing out some theoretical implications of the logic of occupation being cultivated there. It suggests that by fusing a determination for autonomy with a transgressive cultivation of new forms of thinking and social practice, the occupations illustrate new criticalexperimental work in the politics of possibility. The underlying logic thus offers some resources for reimagining modalities of resistance to processes of deep neoliberalization; however, becoming receptive to them may also require a critique of professional academic subjectivities and reevaluation of attachments to existing forms of the university itself. REPRESENTATI ONS 116. Fall 2011 (c) The Regents of the University of California. ISSN 0734-6018, electronic ISSN 1533-855X, pages 62-87. All rights reserved. Direct requests for permission to photocopy or reproduce article content to the University of California Press at http://www. ucpressjournals.com/reprintinfo.asp. DOI:10.1525/rep.2011.116.1.62.
} 
in which consumer demand, in the form of student choice, is sovereign in determining what is offered by service providers." ${ }^{3}$ Revelations of the scale and depth of these plans came in fast-moving waves following the publication of key government texts. The first was the long-anticipated Independent Review of Higher Education Funding and Student Finance, commissioned in 2009 by the outgoing Labour government to review the implementation of the country's first "variable" fees regime in $2004 .{ }^{4}$ It recommended increasing fees, expanding student loans, introducing new forms of hierarchical competition between institutions, and deploying state resources to marketize the entire system.

Importantly, while claiming to be based on consultancy and localized research, the Browne recommendations deviate little from a "world reform" orthodoxy propagated by the World Bank, the International Monetary Fund (IMF), and the Organisation for Economic Co-operation and Development (OECD) since the 1990s, which defines higher education reform almost exclusively as a project of refunctioning for the "knowledge society." ${ }^{5}$ The recommendations display key elements of structural adjustments that have been transforming universities globally since the 1970s, including the expansion and diversification of higher education systems for economic purposes; the shift from public to private funding for universities and the construction of political mechanisms to facilitate their competitive marketization; the subordination of academic governance, professional identities, and intellectual cultures to market rationalities; and the redefinition of publics as clients and students as consumers or knowledge entrepreneurs. ${ }^{6}$ The recommendations also normalized an ideology of university reform that, since the 1980s, corporate powers, politicians, and some vice chancellors have insisted is both necessary and progressive. ${ }^{7}$

The "necessity" of these changes was produced and confirmed in a second text published some weeks later-the government's Comprehensive Spending Review, which outlined departmental settlements for the nation's fiscal-crisis "austerity" budget. In the context of a 25 percent reduction to public spending, it announced a 40 percent cut to the existing higher education budget, including up to 80 percent of funds for teaching in all subjects, translating into a withdrawal of all support for teaching in "nonstrategic" fields. "Institutions which are chosen by students because they offer better quality, responsiveness and value for money," the ministry clarified, "should be able to grow if they wish and-if necessary-at the expense of those that perform less well." Universities now must privatize and compete against one another for extremely scarce resources in a deregulated education market or elect to perish in what promises to be a wasteland of structural and cultural irrelevance.

These proposals are not anomalous in the postwar history of the English university. The subordination of intellectual work to market rationalities initiated by Margaret Thatcher was described in the 1980s by one politician as a 
"Kulturkampf" against academics. ${ }^{9}$ Universities have really been only quasipublic since they began charging international students in 1979, and became incrementally privatized as national fees were introduced in 1998 and trebled in 2004 by Labour governments; they were subsumed into a Department for Business, Innovation and Skills in 2009. Any sense of a sudden attack on the public university here is out of joint. But by finally subordinating all knowledge and educational relationships to crude market ideologies and mechanisms of economic exchange, the policies go beyond the tactical reforms that have accumulated in recent decades to constitute a politico-ideological strategy that denies the very possibility of the public university and institutionalizes political mechanisms to mitigate its future realization in any form. This distinguishes a long period of neoliberalization from a new settlement of what Neil Brenner, Jamie Peck, and Nik Theodore refer to as "deep neoliberalism."

Neoliberalism is an imperfect name for the ascendant rationality of governance in which "all dimensions of human life are cast in terms of a market rationality" and, in England, where the role of the state is to deploy a variety of strategies (including privatization, deregulation, reregulation, commercialization, and marketization) to create environments where this can be accomplished without resistance or, preferably, by enthusiastically self-governing subjects. ${ }^{10}$ Deep neoliberalism, as opposed to its disarticulated varieties, began to consolidate in the late 1990s after "successive rounds of distinctively patterned, market-oriented regulatory restructuring" created hospitable conditions for market rationalities and mechanisms to be implemented across institutions "in which processes of marketization and commodification had previously been constrained." ${ }^{11}$ While Brenner and others use the concept to theorize global regulation, it is also useful for conceptualizing the shift from a cumulative implementation of neoliberal practices to a consolidated restructuring of the "rule regimes" governing the finance, management, and social function of higher education itself. Or, to put it in Michel Foucault's terms, we move from a complex field of governmental technologies and strategies of resistance to a relative state of domination in which "the relations of power, instead of being variable and allowing different partners a strategy which alters them, become themselves firmly set and congealed."12

Although this shift has wide-ranging consequences for all of academic life, there are particular implications for the arts, humanities, and critical social sciences. For these disciplines, as James Vernon argues, "speak to different systems of value, different orders of pleasure and enjoyment," and thus cannot assimilate to market logics without being somehow transmogrified or negated. ${ }^{13}$ For many in these fields, therefore, the proposals not only threaten passions, livelihoods, research, teaching programs, and institutions but also promise a Procrustean existence. By the beginning of 2011, through a fog of "depressive disorientation" in the critical corners of the academy, one thing therefore was 
clear: English universities are in crisis again. ${ }^{14}$ Mortality has become a common currency of political expression: philosophers protest that the government is "putting the university to death"; students carry cardboard coffins painted with the epitaph "R.I.P. education"; education is "on life support" according to a flatlining placard; a skull-adorned banner simply requests, "don't kill the arts" (fig. 1). ${ }^{15}$ The moment has been described, in no particular order, as a dark time, tsunami, nuclear catastrophe, nightmare, and act of vandalism. Indeed, whilst such possibilities were on the horizon for decades, "such far-reaching transformations, with their apparently utilitarian rationale, have never before been contemplated" by many inhabiting the university today. ${ }^{16}$

But this is not significant simply because the future of the critical disciplines within English universities is so uncertain. All moments of crisis imply loss for someone, and that this crisis may now mean the loss of the arts, humanities, and social sciences does not make it objectively worse. For while there are material threats to critical disciplines and the right to education, resistance to these threats has also proliferated the production of critical knowledge in new forms and new public spaces-demonstrations; occupations; creative direct politico-intellectual actions such as counter-mapping; read-ins and teach-outs in museums, supermarkets, train stations, and banks; "dances against the deficit"; art and theatrical interventions; and nomadic free schools. ${ }^{17}$ According to one commentator, "Philosophy hasn't been this newsworthy (or energetic) since Ludwig Wittgenstein threatened Karl Popper with a red-hot poker." 18

What makes the conjuncture singular is thus not that the critical disciplines are dead, but that the balance of forces in the struggle to secure their position within the universities has tipped, and for reasons widely felt to be beyond traditional forms of democratic accountability. Even many people advocating privatization have protested that the state had no mandate for disavowing responsibility for higher education-much less for redirecting public funds into the student loans that will enable it to do so. ${ }^{19}$ It was thus above all the government's hostile response to opposition-its racing through of a tightly whipped parliamentary vote to raise fees despite dissent, its deployment of violent policing to discipline the student opposition, and its cavalier use of Dickensian language to justify social inequality—-that heightened university politics into concerns about an attack on democracy itself. According to one critic in the House of Lords, speaking after the House of Commons had already adopted the recommendations on fees, the changes

will switch the concept of universities from being a public good, as they have always been in modern history . . . to, in essence, a private-sector market that is driven by personal-private investment. . . . Some might want to advocate it, some might want to fight it, but everyone must acknowledge that, as a concept for our universities, it has never once been debated and analysed in this House. ${ }^{20}$ 


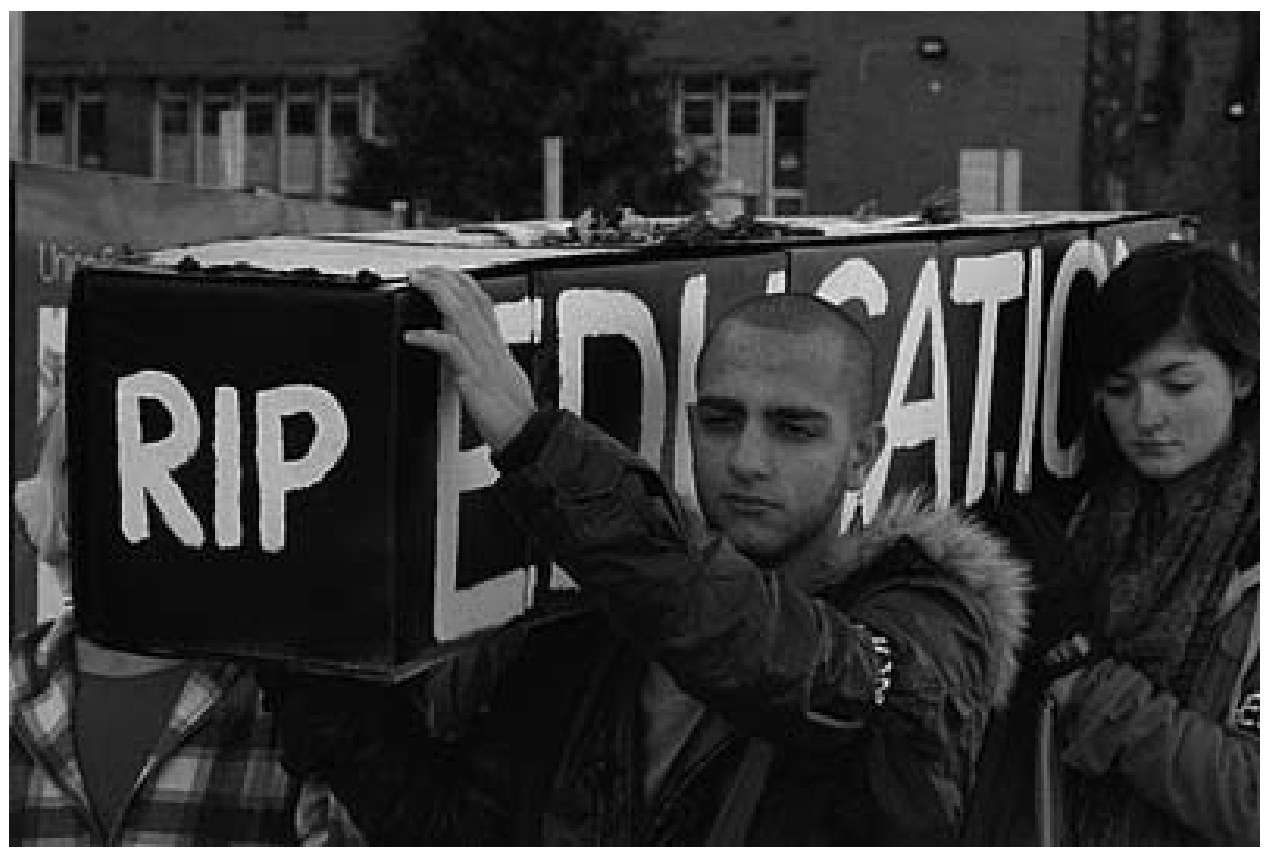

FIGURE 1. Newcastle Occupation, symbolic funeral for education, November 2010. From left to right: Eve Green, Hussein Rabee, Saskia Neibig. Photo courtesy of Steven Alice Lee.

It soon became clear that these were not educational reforms at all, but communiqués pronouncing the creative destruction of the public university system and the futility of its contestation on intellectual, professional, political, or moral grounds.

Thus was accomplished a thirty-year project to "close off and render impossible the experience of education as a collaborative pursuit of a public good and to make possible its full commodification"-and this makes invidious new demands of anyone concerned for the future of democratic higher education. We can fatalistically declare defeat in the face of what has been described as a cultural and economic tsunami, or become more radically open to new conceptions of professional practice, modalities of political resistance, and imaginaries of the future-including those in the realm of "untested feasibility." 21 This is not a moment at which some correct critical judgement could lob history back into our court and magically restore all that which we fear might be dying. On the contrary, the crisis is that in this knowledge we are nevertheless called upon to advance democratic education on unfamiliar, less hospitable, and more culturally disarming terrain. 


\section{Undermining the Academy}

Neoliberalism is now not only "in the house" in English universities but also fast becoming constitutive of the very criteria of what counts as education itself. ${ }^{22}$ But who opened the door to let it in? And why has it become so difficult to just politely show it out? Empirical research on neoliberalization suggests-and the English case is no exception-that policies of privatization, marketization, and corporatization cannot simply be transposed onto existing social forms. While neoliberal interests may be powerful, institutional change in even quasi-democratic contexts is often opportunistic, going only so far, as and when oppositional rationalities and practices ultimately permit. The fact that national tuition fees were introduced in England nearly two decades after first being mooted and raised six years later by a parliamentary margin of only five votes, for example, indicates that the university has not been neoliberalized at will or overnight. But this raises questions. Given that the present crisis was anticipated, why do many students and academics feel so ill-equipped to respond effectively? And what has enabled a minority to undertake bold experiments in political resistance and cultural transformation?

We can shed light on these questions through various narratives-of a historical trajectory from autonomy to heteronomy; a capture of institutions; a colonization of the cultural lifeworld by systems of industry, finance, and governance; or an enclosure by corporate power. ${ }^{23}$ But while offering important insight, none really illuminates how neoliberal rationalities and practices actually displaced critical intellectual ones. For thinking through this problem, the notion of undermining offers some assistance. To undermine something is to "erode its base or foundation," to "dig or excavate beneath [it] so as to make it collapse," or to "make it less powerful or effective, especially in a gradual or insidious way." ${ }^{24}$ In military terms, undermining refers to the slow, labor-intensive work of hollowing out the bedrock beneath a fortress whose ordinary defenses are otherwise impenetrable by the weapons available to opponents seeking its demolition or control. When a hollowed-out fortress finally collapses, it does so hard and fast-all its defenses, perhaps still in full working order, rendered perplexingly useless. Undermining is a form of structural adjustment, but an insidious one that is difficult to observe and thus even harder to resist.

In English universities, neoliberalization has been accomplished in large part through the undermining of institutional practices and political subjectivities in which social, intellectual, and ethical rationalities make more sense-and have more political teeth-than economic and technological ones. How might this work in practice? Wendy Brown has suggested that "neoliberal governmentality undermines the autonomy of certain institutions 
from one another and the market . . . an independence that formerly sustained an interval and a tension between capitalist political economy and a liberal democratic political system." ${ }^{25}$ Applying this to the subjective experience of academic life, Bronwyn Davies and Peter Bansel illustrate how micropractices of neoliberal governance within universities create "a slippage" from autonomous political agents toward "the neoliberal subject whose morality is intimately muddled with that of the entrepreneurial institution whose project is a pragmatic one of survival within the terms of government." ${ }^{26}$ Deep neoliberalism, therefore, moves beyond daily erosions of autonomy to become a hollowing out of the relationships, ideas, and subjectivities that help maintain critical spaces from neoliberal rationality and a temporal contracting of the distance between these spaces. If we can identify how and why these processes become possible, we might also get a better grip on how critical spaces can be reclaimed or created. ${ }^{27}$

\section{Dealing with Idealists: The "Efficiency vs. Democracy" Debate}

No stylized ideal of autonomy has ever been actualized within English universities. Nevertheless, the idea that universities are socially protected spaces for autonomous inquiry and critique has grounded a belief amongst many scholars that teaching, research, and the governance of the university should be relatively autonomous from the logics of both state and economy. This imaginary of the historical university wedges open some of the most resilient gaps between market and nonmarket rationalities and in Britain has roots in an institutional history in which, until the 1960 s, "deference to [universities'] autonomy was entrenched at all levels, including government, even though the system was funded both for recurrent and capital purposes by the [Universities Grants Committee], which was an agency of the state." ${ }^{28}$ It is often forgotten that this independence was itself a contingent effect of power; an elite and "gentlemanly" understanding between elements of a ruling class whose exclusive education corresponded neatly to exclusive privileges of economic and political power. But this misremembering is also a way of drawing on the promise that at least some of these elite privileges-free access to university on merit, intellectual autonomy from the logics of state and market, and the right to a broadly liberal education-would be democratized through university expansion. ${ }^{29}$

From the late 1970s, however, the British state began redefining universities as businesslike institutions operating in the interests of the national economy. ${ }^{30}$ Growing numbers of students were thus accompanied by steadily declining public support for higher education, whilst scholars were increasingly pressured to 
produce "value for money" and to demonstrate, through a range of audit exercises, that their labor is worthy of public investment. ${ }^{31}$ While governments across the Anglophone world were encouraged by international organizations to expand higher education on these terms, they were also warned that democratic cultures would present obstacles to the project. A 1988 World Bank report, for example, cautioned that

in the case of public universities, the faculty have additional means with which to resist threats of radical change and job loss: the idea of the university as a proper and necessary bastion of continuity and tradition; the tradition of academic freedom; and the army of students, former students, and would-be students, most of whom are articulate, energetic, politically volatile, and generally able to be enlisted in the cause of opposing the government's efforts to radically alter their university. ${ }^{32}$

What does a careful reading of this passage reveal? Yes, that the desire to privatize universities goes all the way to the top. But it also affirms things that many academics barely dare to believe any longer: that ideas have political power, that traditions of academic freedom can be used to defend against antidemocratic practices, and that critical knowledge and the will to autonomy both present serious challenges for the neoliberal agenda.

The "Warwick Affair," as it came to be called, offers insight into how important these resources are and why they have been undermined. As a "new university" created in the 1960s, Warwick trialled a novel form of organization-one that would have been impossible to impose on the "older," faculty-governed universities-in which the authority of academics was subordinated to an administrative council composed of academic representatives and politico-industrial "laypersons." 33 Following power struggles between the two, in 1968 the council commissioned a corporate review of operations. The report concluded that the university was "inefficient by normal commercial or industrial standards," and academics were mostly to blame. "Academics tend to be idealists," it asserted, "and they find any conflict between the ideal and the pragmatic correspondingly distasteful." In particular, their preference for democratic process had created an "amorphous and time-wasting system which . . . led to needlessly protracted argument, dilatoriness in the taking of decisions, uncertainty regarding the effective centres of power and action, and at times to conflicts of policy." ${ }^{34}$ The university was no place for democracy, it insisted, and eventually would "have to come to terms with the age-old conflict between democratic principles and effective government."

In 1970, after antagonistic negotiations over a student-union building project, the council refused students' demands for their own substantive self-governance. Several hundred occupied the university administrative building in protest, discovering political files that were being kept on left-wing academics 
and students. Faculty were shocked, and according to historian E. P. Thompson, the events fostered a "paralysis of will ... in any general exertion of control over their own institution." ${ }^{35}$ He argued the "outcome of this episode will ... be some kind of an index of the vitality of democratic process-and of the shape of the next British future." ${ }^{36}$

It was. The constellation of issues in the Warwick Affair-the revelation of corporate domination in academic governance, student governance, and labor rightsin a new type of business-oriented university-shaped its specificity. But variations on the logic underlying this high-profile case were transforming other universities across the country during the 1970s and 1980s as well. In 1985, for example, a group of university vice chancellors commissioned a review of selected universities, which explicitly asserted that universities were "first and foremost corporate enterprises to which subsidiary units and individual academics are responsible and accountable." 37 To remain competitive they must thus reeducate academics, who for reasons unintelligible within corporate logic, "sometimes see their academic disciplines as more important than the longterm well-being of the university which houses them." Ominously, the report also concluded that the "attitude of the mind of the staff" in universities needed to be altered for such reforms to be successful. This in turn depended upon the extent to which traditions of autonomous governance and critical subjectivities could not only be disempowered but also replaced by new modalities of control. Vice chancellors were transformed into CEOs, and "inefficient" committees were replaced by bureaucratic lines of managerial authority. The "tenure problem," as tenure was called, was resolved through its abolition by an act of Parliament in 1988; also abolished was the academic-led University Grants Committee, which had since 1919 allocated public funds to universities while providing scholars "a significant amount of protection from commodifying measures." 38

These processes of corporatization have had formidable consequences over the years, resulting in what some anthropologists regard as an "epochal change" in the culture of the academy and educational work. ${ }^{39}$ By the 1990s, many academics in England inhabited universities that they did not govern in accordance with their own intellectual rationalities, in which they could not fully control their own pedagogical and research practices or recognize themselves as efficacious political beings. For "although the structures of a former self-governed, self-managed, sector remain largely in place ... they no longer have substance but rather serve to conceal the state's control of policy." ${ }^{40}$ Now, even as many of these hollowed-out structures are being dismantled, it emerges that there are few foundations left to keep them standing. 


\section{Liberation Through Debt: \\ The Compulsory Privatization \\ of Neoliberal Dirigisme}

Such strategies for subordinating critical rationalities to the logic of the market in academic work have been largely invisible to many university students. However, the effort to transform educational relationships into economic exchanges also subjectifies students. In order for the state to privatize public universities it must force students to pay, persuade them that they should pay, or convince them there is no alternative. The piecemeal transition from public to private funding in England has thus been accomplished through a combination of defunding, a framing of systemic "crises" as the inevitable consequence of unreasonable demands for public education, and the characterization of private investment as the only rational means of funding universities. This tactic of simultaneously inducing and managing crises took shape in the late 1970s when, prodded by the IMF, Thatcher's government introduced tuition fees for international students and reduced university budgets by a corresponding amount. In arguments similar to today's, many institutions argued that this manufactured budget crisis compelled them to accept Thatcher's policies. ${ }^{41}$ By the early 1990 s, many vice chancellors were either resigned to or invested in privatization and lobbying government for the power to charge "home" students fees as well. What students called the "race to turn many great state institutions into private universities" had begun. ${ }^{42}$

Under continuing pressure from vice chancellors and despite considerable public opposition, the New Labour government broke precedent and introduced the first national tuition fee of $£ 1,000$ in $1998 .{ }^{43}$ More than two million students walked out of lectures to protest the plans; some went into occupation. The head of the Committee of Vice-Chancellors and Principals accused them of being "misguided," asserting that fees were the "only realistic way of maintaining the long-term quality of provision in higher education." ${ }^{44}$ In 2004, against further student opposition (then muted by opposition to Britain's invasion of Iraq), New Labour eked through both a threefold increase in fees and a new system for their quasi-deregulated marketization. And in autumn 2010, after more than fifty thousand students marched in anger and as thousands occupied a third of the country's universities, the head of Universities UK urged vice chancellors to accept that as "the cuts to the HE budget are a painful reality," opposing higher fees would have "devastating" consequences. ${ }^{45}$

The creeping of tuition fees into England from the late 1970s to the present day could be interpreted, like other struggles against neoliberalism across the world during this period, as a situation in which "rapid 
economic shifts meant a series of major defeats" for social democratic principles. ${ }^{46}$ Like many of their lecturers, students have adapted to practices of privatization, corporatization, and marketization within the universities. And yet, some in each generation have also resisted this hollowing out of education and of their lives-less through institutional contestation (which has historically been less open to them) than through collective protest and direct action. Against a background of political despair, their sustained and organized responses to the current policies have impressed even skeptical observers. However, while there is much analysis of the "event," character, and political efficacy of these actions, there has been less attention to the cultivation of new political subjectivi-

ties and critical-experimental modalities of resistance ${ }^{47}$ It is to these new formations that we thus turn now.

\section{Practices of Freedom}

The field of struggle within the English university is a messy space of points of view. ${ }^{48}$ The university is dying, being reborn, and evolving; public education is under assault, taking its own life, and bleeding out internally; academic life is mourned, valorized, and mundanely reproduced; and critical thought is grinding to a halt and being revitalized in prefigurative political experiments. We should not be surprised; as Simon Critchley argues, "The massive structural dislocations of our times can invite pessimism, even active or passive nihilism . . . but they also invite militancy and optimism, an invitation for our capacity of political invention and imagination." ${ }^{49}$ In one sense, because neoliberalizing processes and forms of resistance are not all of a kind, they can be understood as a simple multiplicity of strategies through which "subjects are able to say 'enough' and contest, negotiate and modify" their situation. ${ }^{50}$ But can we account for the differences and expand possibilities for critical agency?

For many professional academics confronting the consequences of aggressive policies of neoliberalization, relations of power and possibility appear to have become so fixed that "it becomes impossible to adopt strategies and tactics that can modify them." fatalistic resignation. But for a significant minority, this very blockage has become a catalyst for new struggles against local political decisions and a calling to radically reimagine the future of the university itself. It is here that fundamental questions about political futures have begun to play out in practice. Do we demand recognition and autonomy through representative processes or assert the right of self-determination through more direct forms of political intervention? Should we defend existing traditions and institutions, however imperfect, or transform, transgress, or abandon them? In the 
last instance, although we may see lines of flight, is there really anywhere else to go?

Despite appearances, such questions are not either-or propositions. Processes of neoliberalization are multiple and uneven, and if each "carries the residues ... of past regulatory struggles, which recursively shape political capacities and orientations, and future pathways of neoliberal restructuring," then it follows that resistance also takes many different or even hybrid forms. ${ }^{52}$ James Tully usefully reminds us that judgments about whether to "go on," to attempt reform through existing logics, or to challenge these altogether are all "ways subjects act on their possibilities" or, in other words, practices of freedom. ${ }^{53}$ But which, if any, are also practices of liberation?

\section{Going Forward into the Neoliberal University}

"Transformation" comes in all forms, including the neoliberal. For the architects and builders of this new university, things are "going forward" in a period of hyperactive innovation-responding to changing market demands and public discourses, gaming the rankings, securing superior position against "competitor" institutions. For the winners it is an exciting time, full of risky possibilities. Indeed, as a missive circulated recently at one university asserted, this is no time or place for "negative thinking"; academics were instructed to "be enthusiastic, persistent and courageous supporters in the face of cynicism."

For those who can adapt to the new regime, life will go on in new terms, with new routes to professional recognition. For others more deeply committed to the idea of the public university as a democratic institution governed by a community of scholars and students for educational rather than solely economic purposes, however, academic life is continually disorienting. ${ }^{54}$ On the one hand, this oppositional position does maintain critical distance between nonmarket and neoliberal rationalities, and feelings of frustration, anger, and despair serve as important reminders that at the micropolitical level "neoliberalism is always contingent and can never completely close down alternatives." ${ }^{\prime 55}$ On the other hand, the sedimentation of ritualized professional practices over time neutralizes critical rationalities and disables the will to resist. Given the hollowing out of possibilities for democratic engagement, many people focus on acting "in accord with the rules of the practices in which they cooperate in the variety of ways of going on as usual," subverting them for self-satisfaction if they can ${ }^{56}$ Critical theorization is quiet here, but not because it is despised. Sometimes the reproduction of the bureaucratic machinery affords insufficient time for thought. Other times it hurts to reflect on things that are beyond individual control. 
In either case, beneath the waves of protest and media hype, the neoliberalization of the university is accomplished as an extraordinarily ordinary event.

\section{An Ambivalent Confidence in Form-Defending the University from Within}

But critical responses have also emerged to challenge, resist, and even reverse these processes. Scholars continue to write the crisis, as they have for decades: consider Jean-François Lyotard's Condition of Knowledge (1979), Bill Readings's University in Ruins (1996), Mary Evans's Killing Thinking (2004), and Ellen Schrecker's Lost Soul of Higher Education (2010). There is no shortage of critique; rather, there is an enduring faith that its academic forms remain politico-intellectual weapons of enlightened resistance. It is in part this historical promise of the radical potential of critical knowledge that academics and students are now concerned to defend-not only because it is a familiar mode of cultural resistance but also because it is understood that these principles are important for any democratic project and that they are under threat.

The defense of these possibilities has taken various forms: a silent protest by Cambridge professors (to "insist that the university is not ... a business, but a place of free intellectual activity"), a campaign by the British Academy of Social Sciences (to "amass evidence" of the social utility of social science), a blog by the British Sociological Association (to publicize analysis), work by the UK Council of Heads and Professors of Sociology (to engage in "private diplomacy with politicians"), and a Campaign for the Public University (to "defend and promote the idea of the public university"). ${ }^{57}$ These are not presently coordinated; indeed, there are some tensions between them. But they are bound by a conception of the political in which "subjects raise a problem about a rule of practice" in sanctioned languages and procedures of "negotiation, deliberation, problem-solving, and reform." ${ }^{58}$

So too was the first student-led street demonstration against budget cuts and tuition fees during the autumn of 2010. While represented in mainstream political discourse as being an affront to liberal democracy, it was also wholly recognizable within the "languages of communication and legitimation" used for voicing democratic dissent in British society. Students' early protests affirmed a faith—or at least an avid hope-in a liberal democratic process that many had in fact just discovered. Placards appealed to politicians to "honour their promises," chided the deputy prime minister to "act like an anthropologist" because he was educated as one; and accused the government of cheating young people out of promised futures (fig. 2). The prevailing logic, even of the controversial occupation of the Conservative 


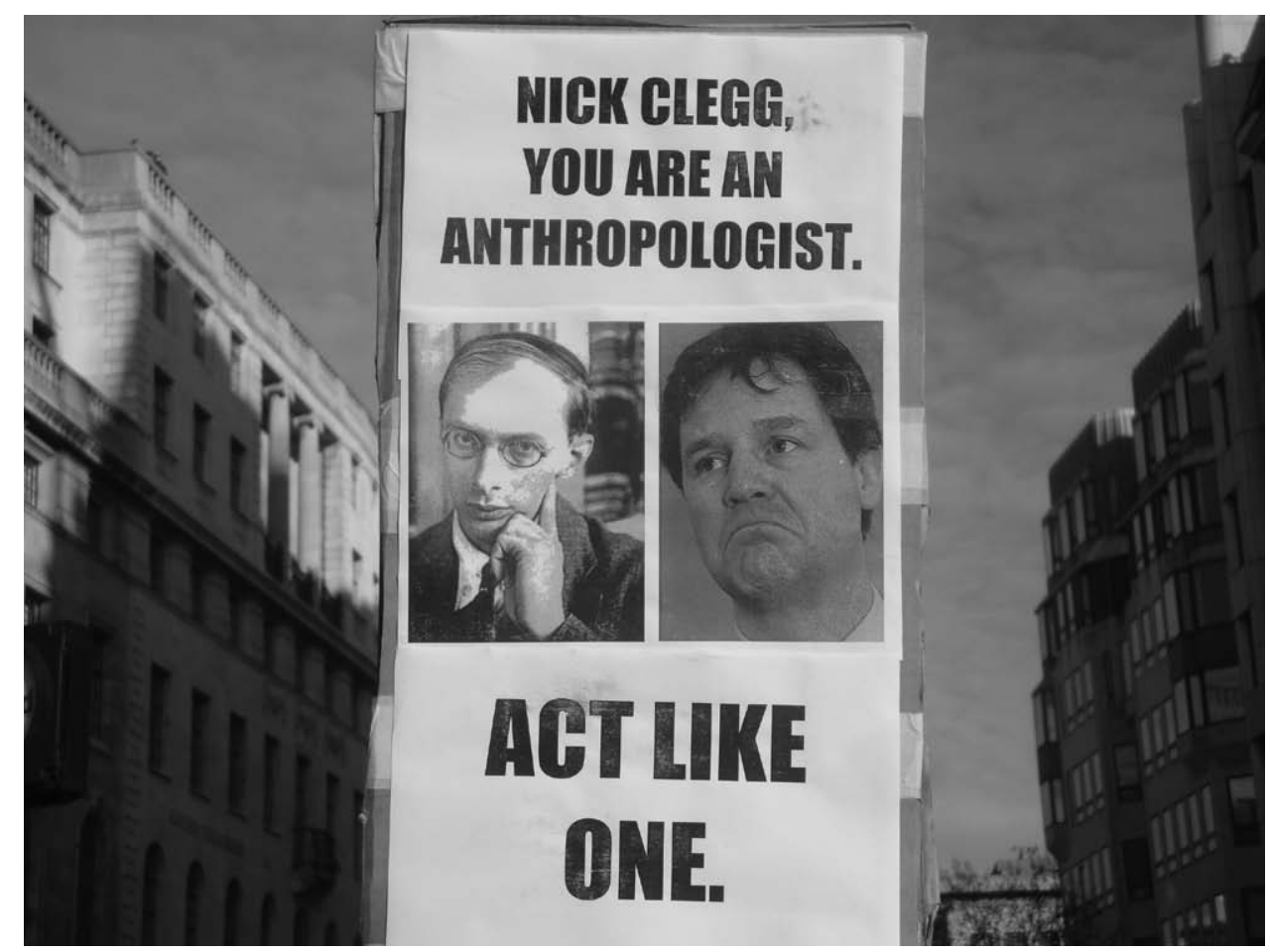

FIGURE 2. "Nick Clegg, you are an anthropologist," demonstration placard. December 9, 2010, London, "Day X3," third national protest against increase in undergraduate tuition fees at English universities. Photo courtesy of the author.

Party headquarters during the demonstration, was to reassert the rules of democracy: where the state violates them, the people protest-play fair.

These actions are often dichotomously opposed to others regarded as radical (in populist discourse, meaning disproportionate and irrational), particularly the recent student and citizen occupations of university buildings, shops, and public spaces that have proliferated both in Britain and across Europe. Although these actions have been characterized as unprecedented, previous occupations had been organized to demand that universities break their silence over Israel's attack on Gaza in early 2009 and to resist institutional restructuring at three universities in early $2010 .{ }^{59}$ According to one woman, therefore, "as students in Britain were looking up nervously at the butcher's knife of government spending cuts hanging precariously over them, we knew what to do. ${ }^{" 60}$ In autumn 2010 they occupied fifty universities. ${ }^{61}$ On the one hand, occupiers demanded that vice chancellors oppose the budget cuts, tuition fees, and broader neoliberalization of education. 
On the other, they cultivated spaces to practice and prefigure radically democratic forms of education and governance within the universities. These were paralleled by ephemeral occupations of high-street stores in a campaign to raise awareness about corporate tax evasion, and of city council buildings to interrupt budget-setting meetings. It made the news: university students were radicalizing again and bringing lecturers, workers, journalists, parents, and children along with them.

But these actions defy easy categorizations of "liberal" or "radical." Most of the occupations defended traditional academic values of intellectual freedom and critique, the idea of the university as a public good, and principles of representative democratic process. In seeking to save academic programs from arbitrary closure and workers from unfair dismissal-and thus acting as emergency brakes on the contraction of time and space for political intervention-students have employed a range of classically "liberal" tactics such as the presentation of evidence, publication of analysis, initiation of dialogue with management, and petitioning. There has been much work "to call a rule into question and negotiate its modification" by demanding that institutions honor their rhetorical principles of democratic governance.

What radicalizes such practices within the context of an occupation, however, is that they are problematized within an alternative reading of power that hopes but does not presume that these principles can be defended within extant institutional forms. What thus may be under certain conditions a reformist practice of calling logics into question thus becomes a performative act of resistance. Its aim is not to engage in an ongoing game of strategic struggle but to short-circuit relations of power that are understood to have become, as Tully describes it, "not open to challenge, negotiation, and reform." ${ }^{\text {" } 2}$ When students occupying the Old Schools at Cambridge in November 2010 demanded that the university "ensure the autonomy of education from corporate interests," for example, they "had no illusions that the University would do any such thing (and ... were proved right)." But this was no failure, according to one student involved-indeed, one of the major achievements of the occupations was to erode the myth of a cozy academic community as an oasis of humanism in an inhuman world, set apart from capitalist society." ${ }^{\prime 63}$ This is not a rejection of liberal democratic values or of education, but an assertion that those in control of the institutions that claim to represent them do not.

This raises the ante for professional academics, many of whom are ambivalently attached to the university. ${ }^{64}$ Materially, it is a primary site of intellectual work and professional recognition, and its wages pay the bills. Ideologically, it is still imagined as, and sometimes is, a space for intellectual activity, free inquiry, enlightenment, and emancipation-a place of relative freedom where it is possible to carve out spaces of alterity in scholarship, pedagogy, and political action. Politically, it is also experienced as an alienating and repressive arm 
of the state-capitalist apparatus. The university is at once real, nostalgic, and utopian-and the more distance grows between the desire and its eventualized forms, the more effort seems to be channeled into repairing the latter.

What if, though, these historical promises of the university were divorced from their institutional home, or if they were there transmogrified and undermined? What if moderated requests for recognition and autonomy were met with professional exclusion or state violence? What if higher education was no longer intelligible as a social democratic institution, or the university became occupied by a rationality hostile to the raison d'être of the critical disciplines? What then would we defend, and how?

\section{"We don't want to defend the university, we want to transform it!"}

Such a reading of the critical disciplines' current predicament is now emerging, and within the academic profession it seems to be engendering demoralization and despair. But amongst a certain loose grouping of left-politicized students across Britain (and in different ways in the South, East Asia, Europe, and the United States) it has hastened a shift from conceptions of resistance as subversion or opposition to one of resistance as transformation. ${ }^{65}$ The student-led occupations have thus been inspirational for others in wider anti-austerity struggles. The president of the National Union of Journalists, for example, wrote that "the student occupations have lit a fire under the whole movement-they have shown all of us the power of resistance." ${ }^{" 66}$ According to another commentator, they have "played a concrete role in widening the realm of the possible beyond the constrictive paradigm of the status quo and "common sense." 67 This expansion of possibility matters, as it approaches in everyday practice what Nikolas Kompridis argues philosophically is a critical response to crisis- the "disclosure and realization of possibilities for going on with our practice more reflectively, cooperatively enlarging the space of freedom as we cooperatively enlarge the space of possibility." 68

It is not that many academics disagree with the diagnosis. Indeed, all the metaphorical invocations of death and dying suggest they sense it all too well, and as one philosopher said after seeing his students beaten at a demonstration, "With each new protest, we learn a little more about what we are up against." ${ }^{69}$ But for those who feel their own futures to be intertwined with the survival of the neoliberal university, the example is less a mobilizing call to arms and more of a disarming summons to do a "different reading of our attachments and possibilities." ${ }^{\text {" }}$ To acknowledge that familiar "institutions and strategies of problematization and reform are either unavailable or fail because those who exercise power can subvert or bypass them" is unsettling, 
as it presses toward forms of thought, feeling, and action that do not integrate easily into professional academic subjectivities. ${ }^{71}$ When students say, as some do now, "We don't want to defend the university, we want to transform it," they are also calling academics to account, both for what we do now and for what we might become. ${ }^{72}$ They are-variously and not entirely coherently-rejecting, reclaiming, reimagining, and trying to repurpose universities that have been undermined on our watch. It is thus not surprising that some students decided "it was time to take our campuses back into our own hands." ${ }^{\prime 3}$ But given the extent to which academics deplore and critique the undermining of education and research, it is more surprising that students are often left so alone in doing so.

In the final part of this paper, I thus want to explore how the political logic of occupation that has been articulated by student activists as one kind of response to the current crisis of the English public university might be used to inspire a more radical imagination about other forms of resistance and creation. My aim is not to valorize occupation as a tactic of resistance. As Stevphen Shukaitis and David Graeber insist, "There is no pure social space in which new practices and ideas will emerge from a revolutionary subject that we only need to listen to," and many who were involved in recent occupations insist that they must not be abstracted from more holistic theorizations of the political. ${ }^{74}$ Rather, I am interested in the fact that they have found ways to disrupt logics of power that are very effective in suffocating hope and to make mental, physical, and temporal spaces for cultivating alternative ways of thinking and acting together.

\section{The Logic of Occupation and the Politics of Possibility}

There is no unifying model of occupation. Even a cursory survey of texts written for specific actions reveals both a rhizomatic search for historical and contemporary inspiration and qualitative differences between the violent definition of occupation as a "car bomb" that "explodes time" and its depiction as an aesthetic exercise in "beautiful" transgression. ${ }^{75}$ Participants have also produced a plethora of critical reflections on the problems that have arisen during specific occupations, such as the fragmenting of new political relations by old political schisms, the merits of top-down and horizontal organization, the hidden hierarchies of consensus politics, the artificial division of "politics" from everyday life, and the risk that celebrating aesthetic autonomy is just another proxy exercise in class domination. ${ }^{76}$ These writings suggest that far from being a merely political form of resistance (a charge leveled more at middle-class university students than at factory workers or landless movements), the acts have been exercises in the politics of possibility itself. 
The "politics of possibility" is J. K. Gibson-Graham's name for an emergent political imaginary that has been "radically altering the established spatiotemporal frame of progressive politics, reconfiguring the position and role of the subject, as well as shifting the grounds for assessing the efficacy of political movements and initiatives" in recent years. ${ }^{77}$ As neoliberal governance is an emergent political formation, responses to it must be fresh as well; and where trusted practices of resistance fail, we learn that we must learn what the new forms might be. A politics of possibility is not intimidated by this understanding. Rather, it helps conceptualize such limit-situations as the conditions of politics itself and aspires to "build a politics that acts in the moment, not to create something in the future but to build in the present, it's the politics of the here and now." 78

Applying this logic to the present crisis of the English university, therefore, it is thus possible to understand that while the "proposed reforms triggered large student demonstrations [that] had no impact on any constituency of real influence either in the universities or in politics," this is a limitsituation to be encountered through yet-untested modalities of resistance, rather than the limit of possibility itself. ${ }^{79}$ As Parliament was passing the legislation that accepted the proposals for university restructuring in December 2010, for example, two demonstrations were held. One was a small candlelight vigil organized by the National Union of Students to mark the closure of the possibility —and thus the legitimacy—of critique and resistance. The other was a thirty-thousand strong protest organized by a network of student activists, for whom the passing of the vote was both anticipated and illegitimate, and marked the emergence of a new political terrain upon which new ways of thinking and being must be formed. "No need for a vigil," wrote Clare Solomon. "We were celebrating the birth of a movement, not the death of education." $" 80$

As the mother of one student wrote, this will to "resist unfair treatment, to question a false narrative of necessity, and to protect the fragile gains of decades of expansion of higher education" evidences a critical attitude to present and future-one that critical theorists argue is vital for cultivating practices of freedom in conditions of relative domination. ${ }^{81}$ It thus bears thinking about occupation not as a model of political action but as one articulation of an ethos of critical experimentation that shifts "critique conducted in the form of a necessary limitation into a practical critique that takes the form of a possible transgression.. ${ }^{82}$ It is neither out-there-and-someday-when-conditions-are-right nor in-here-apart-from-others-because-conditions-are-wrong; rather, it is an attitude toward being that struggles to expand and resignify space and time while inhabiting them with others. ${ }^{83}$ But in order to engage it, we must first be able to see "what is opened as a possibility when something that has claimed us is finally put to rest." 84 
What often claims professional academics is a hope that the exercise of deep neoliberal power can still be arrested, reversed, or at least adequately mitigated by institutionally sanctioned resources of resistance. There seems to be a fear that calling this into question would be a betrayal of commitments to critique, reasoned argumentation, intellectual autonomy, and the promises of the university as a democratic institution. "Can we bear to withdraw our consent to the forms that have pacified us through promising representation," as Lauren Berlant has elsewhere asked? ${ }^{85}$ We know that our universities are not fully democratic institutions and yet, because we inhabit them ambivalently, cannot quite believe that they are otherwise. We continue to assert the political authority of the critical academic even when bypassed or suppressed; one student paper reported what should be a paradox: "Protests Prove Academic as Government Wins Fees Vote." channeling critical intellectual work into the logics of the neoliberal corporation, distorting our words and minds simply so that we might survive the broader structural transformations without being too much transformed, we have forgotten that "the philosopher can only participate in social struggles so long as he is not a professional philosopher."

One insight gained from the emergent student resistances is that while the critical-experimental ethos is a necessary component of any response to processes of deep neoliberalization, it is not sufficient-that, indeed, it must be defended through political struggle. Are there tensions in this space? Yes, and this is where new theorizations must begin. Apart from a minority of scholar-activists, however, and despite the understanding that the neoliberalization of higher education in this way is also an attack on democracy, few academics regard the university as a site of struggle, or education as a reason for it. The future thus appears bleak: we can become intellectual automatons, perform loyalty to the corporation and carve out cramped spaces of freedom for teaching and serious intellectual work, or abandon the university as a social project altogether. But a logic that has been made visible through current student-led politics discloses a fourth option, which is what Tully describes as the possibility of making "cautious experimental modifications of our specific forms of subjectivity"-including (or especially) those we undertake as we "go on" in conditions of crisis, and in which we ground our everyday practices of freedom. ${ }^{88}$

Resistance notwithstanding, it is likely that the English university will continue to be privatized, marketized, and repurposed to further serve the interests and fulfill the desires of the capitalist classes. People understand this; hence the adaptations, defenses, transformative experiments, and exoduses. But it need not follow that the university, and more specifically its unfulfilled emancipatory promises, are dead. As an "intellectual pattern," a hypothesis of the possible, it does not die simply because it is displaced, unless we fetishize 
its extant forms as the limits of its possibility (fig. 3) ${ }^{89}$ The pressing question in England now may not be whether the public university will survive but how anything like democratic education will be possible despite its deep neoliberalization. Or even better to ask more imaginatively where, how, and with whom the project will be advanced in conditions so deleteriously undermined.

The students who have been protesting on the streets and occupying the universities here admit that they do not have definitive answers to these questions and that they cannot answer them alone. But they have most vociferously rejected the injunction that there can be no answers at all and demonstrated what it takes to engage practically in the awkward, messy, joyful, and risky work of thinking and acting differently in seemingly frozen states of domination. "You fight the closing down of possibility," writes one, "by opening it up, by widening the field of potential historical actors-we are engaged in a battle over the conditioning of the future." ${ }^{\prime 90}$ Can we learn what we have been trying to teach all along? It's worth a thought.

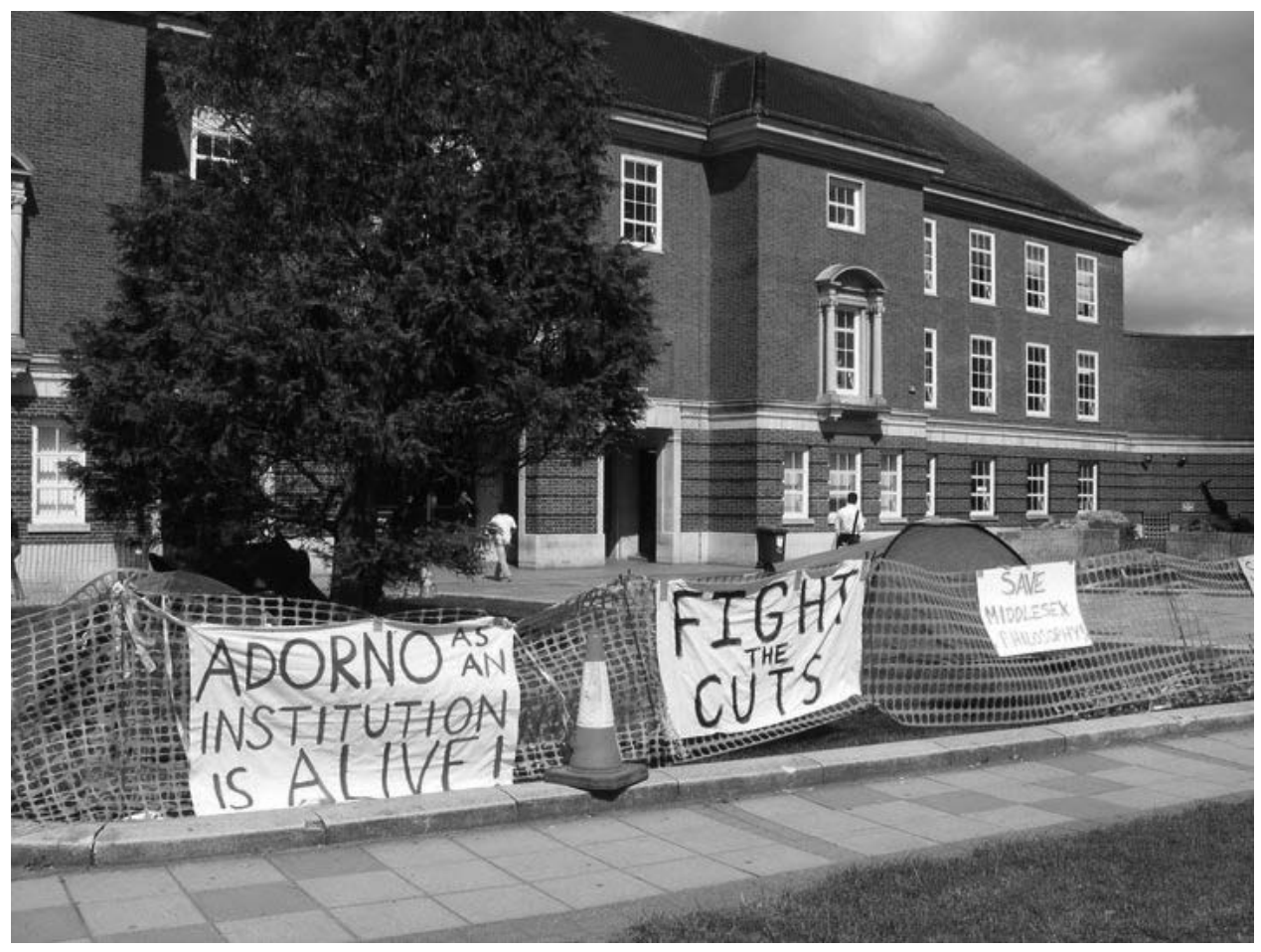

FIGURE 3. "Adorno as an institution is alive!" University of Middlesex Occupation, May 2010. Photo courtesy of Jo Bevin and Ally Moss. 
I am grateful to Colleen Lye, Chris Newfield, and James Vernon for their useful and challenging comments on earlier drafts of this paper; Mahmood Delkhasteh, Nancy Weiss-Hanrahan, and Karen West for their comments and criticisms; and Jean Day for her editorial work.

1. Jeremy Gilbert, Anticapitalism and Culture: Radical Theory and Popular Politics (Oxford, 2008), 174. For a discussion of the neoliberal turn, see David Harvey, "Neoliberalism as Creative Destruction," Geografiska Annaler 88, no. 2 (2006): 145-58; and Jamie Peck, Nik Theodore, and Neil Brenner, "Postneoliberalism and Its Malcontents," Antipode 41, no. S1 (2010): 94-116.

2. Independent Review of Higher Education Funding and Student Finance, "Putting Students First: A Radical Plan for Choice," October 2010, National Archives (UK), snapshot taken January 19, 2011, http:/ / hereview.independent .gov.uk/hereview/wp-content/uploads/2010/10/Browne-Report-Release.pdf.

3. Stefan Collini, "Browne's Gamble," London Review of Books 32, no. 21, November 4, 2010.

4. Lord Browne, An Independent Review of Higher Education Funding and Student Finance in England, October 12, 2010, National Archives (UK), snapshot taken January 19, 2011, http:/ / hereview.independent.gov.uk/hereview/.

5. D. Bruce Johnstone, "The Financing and Management of Higher Education: A Status Report on Worldwide Reforms," The World Bank (1998), http://www .fel-web.org/fel/bolonia/noabolonia.es/bancomundial.pdf, 5. For an early discussion of universities in international economy, see Organisation for Economic Co-Operation and Development, Universities Under Scrutiny (Paris, 1987). For contemporary trends across Europe, see European University Association, "Impact of the Economic Crisis on European Universities," January 2011, http:/ / www.eua.be/Libraries/Newsletter/Economic_monitoringJanuary 2011final.sflb.ashx.

6. For discussions of postwar structural transformations of the university see Craig Calhoun, "Is the University in Crisis?" Society (May/June 2006); Gustavo Fischman, Sarah Igo, and Diana Rhoten, "Are Public Research Universities in Crisis?" Reencuentro 050 (December 2007), 117-30; and Michael Peters, "The Posthistorical University? Prospects for Alternative Globalizations," in Gustavo Fischman et al., eds., Critical Theories, Radical Pedagogies, and Global Conflicts (Lanham, MD, 2005), 69-86.

7. Jeremy Gilbert, "Elitism, Philistinism and Populism: The Sorry Tale of British Higher Education Policy," OpenDemocracy, January 14, 2000, http://www.opendemocracy .net/ourkingdom/jeremy-gilbert/elitism-philistinism-and-populism -sorry-tale-of-british-higher-education-p.

8. Department for Business Innovation and Skills, Letter on "Higher Education Funding for 2011-12 and Beyond," December 20, 2010, http://www.bis.gov .uk/assets/biscore/higher-education/docs/h/10-1359-hefce-grant-letter-20 -dec-2010.pdf.

9. John Beck, "Makeover or Takeover? The Strange Death of Educational Autonomy in Neo-Liberal England," British Journal of Sociology of Education 20, no. 2 
(1999): 225; see also Stuart Hall, "The Emergence of Cultural Studies and the Crisis of the Humanities," October 53 (1990): 11-23.

10. Wendy Brown, "Neoliberalism and the End of Liberal Democracy," in Edgework (Princeton, 2005), 40. For comparable definitions, see Noel Castree, "Neoliberal Environments: A Framework for Analysis," Manchester Papers in Political Economy, Working Paper no. 04/07, December 10, 2007, 8; and Les Levidow, "Marketizing Higher Education: Neoliberal Strategies and Counter-Strategies," in The Virtual University? Knowledge, Markets and Management, ed. Kevin Robbins and Frank Webster (Oxford, 2002).

11. Neil Brenner, Jamie Peck, and Nik Theodore, "Variegated Neoliberalization: Geographies, Modalities, Pathways," Global Networks 10, no. 2 (2009): 214.

12. Michel Foucault, "The Ethic of Care for the Self as a Practice of Freedom," in James W. Bernauer and David Rasmussen, eds., The Final Foucault (Cambridge, MA, 1988), 3.

13. James Vernon, "The End of the Public University in England," Inside Higher Ed, October 27, 2010, http://www.insidehighered.com/blogs/globalhighered/ the_end_of_the_public_university_in_england.

14. The notion of depressive disorientation is adapted from Alain Badiou, "The Communist Hypothesis," New Left Review 49 (2008): 29-42.

15. Alexander García Düttmann, "The Life and Death of the University," December 8, 2010, Goldsmiths Fights Back, http://goldsmithsinoccupation.word press .com/2010/12/08/the-life-and-death-of-the-university-by-alexander-garcia -duttmann/.

16. Bridget Fowler, "The New Mode of Funding," Sociology and the Cuts, January 6, 2011, http:/ / sociologyandthecuts.wordpress.com/2011/01/06/the-new-mode-of -funding-by-bridget-fowler/.

17. To watch a video from the "massive symbolic lecture" at Euston Rail Station, December 8, 2010, see http://www.youtube.com/watch?v=INGkd3CtWHs.

18. Richard Morrison, "Philosophy Hasn't Been This Newsworthy Since Wittgenstein Threatened Popper," Times Online, May 21, 2010, http://entertainment .timesonline.co.uk/tol/arts_and_entertainment/article7132170.ece.

19. Steve Smith, "Where Is the Government's Mandate to Change the World of Higher Education?" Guardian (UK), October 19, 2010, http://www.guardian .co.uk/education/2010/oct/19/universities-change-world-government-funding.

20. Lord Triesman, Amendment to Motion to Approve Higher Education (Basic Amount) (England), Hansard, December 14, 2010, column 559, http://www .publications.parliament.uk/pa/ld201011/ldhansrd/text/101214-0001.htm.

21. "Untested feasibility" is a concept introduced by Paulo Freire in The Pedagogy of the Oppressed (New York, 2000), 117.

22. Wendy Brown, "Why Privatization Is About More Than Who Pays," YouTube video, 16:25, from Save the University: A Teach-in on the UC Crisis, September 23, 2009, uploaded by "calcommunitycontent," September 25, 2009, http:// www.youtube.com/watch?v=aR4xYBGdQgw.

23. For a UK perspective, see Gordon Finlayson and Daniel Hayward, "Education Towards Heteronomy: A Critical Analysis of the Reform of UK Universities Since 1978," University of Sussex, http://www.sussex.ac.uk/Users/jgf21/eth $\% 20$ final\%20version.pdf.

24. Concise Oxford English Dictionary, 12th ed., ed. Catherine Soanes and Angus Stevenson (Oxford, 2008), s.v. "Undermine." 
25. Brown, "Neoliberalism and the End of Liberal Democracy," 45.

26. Bronwyn Davies and Peter Bansel, "Governmentality and Academic Work: Shaping the Hearts and Minds of Academic Workers," Journal of Curriculum Theorizing 26, no. 3 (2010): 14.

27. Stephen Ball, "The Teacher's Soul and the Terror of Performativity," Journal of Education Policy 18, no. 2 (2003): 215-28.

28. Michael Shattock, "The Change from Private to Public Governance of British Higher Education: Its Consequences for Higher Education Policy Making, 1980-2006," Higher Education Quarterly 62, no. 3 (2008): 183.

29. These were all key principles for expansion as laid out in the Robbins Review of 1963. See Committee on Higher Education (23 September), Higher Education: Report of the Committee Appointed by the Prime Minister under the Chairmanship of Lord Robbins 1961-63, Cmnd. 2154 (London, 1963).

30. Auriol Stevens, Lecture 1, UC Berkeley Center for the Study of Higher Education, February 25, 2003, 18, http://igs.berkeley.edu/programs/stevens.doc. See also Jo Halliday, "Maoist Britain? The Ideological Function of Vocationalizing the Higher Education Curriculum," Curriculum Studies 1, no. 3 (1993): 36582.

31. For a discussion of public funding per student from 1980 to 1999, see David Greenaway and Michelle Haynes, "Funding Higher Education in the UK: The Role of Fees and Loans," Economic Journal 113, (February 2003): 152. The Higher Education Funding Council for England argues that the downward trend stabilized from 1999; however, this seems to be because it defines the new privately paid tuition fees as public funds since "both the level of fees and the student numbers are controlled by the government." See the Financial Sustainability Strategy Group, "The Sustainability of Learning and Teaching in English Higher Education,” December 2008, 14, http://www.hefce.ac.uk/finance/ fundinghe/trac/fssg/FSSGreport.pdf.

32. Johnstone, "The Financing and Management of Higher Education," 25.

33. E. P. Thompson, ed., Warwick University Ltd.: Industry, Management and the Universities, (London, 1970), 60-63.

34. Ibid., 137, 81. 35. Ibid., 155. 36. Ibid., 164.

37. Committee of Vice-Chancellors and Principles, Report of the Steering Committee for Efficiency Studies in Universities (London, 1985).

38. Hugh Willmott, "Managing the Academics: Commodification and Control in the Development of University Education in the UK," Human Relations 48, no. 9 (1995): 997.

39. Marilyn Strathern, "New Accountabilities: Anthropological Studies in Audit, Ethics and the Academy," in Audit Cultures: Anthropological Studies in Accountability, Ethics and the Academy, ed. Marilyn Strathern (Oxfordshire, 2000). See also Chris Shore and Susan Wright, "Audit Culture and Anthropology: Neo-Liberalism in British Higher Education," Journal of the Royal Anthropological Institute 5, no. 4 (1999): 557-75.

40. Shattock, "The Change from Private to Public Governance," 182.

41. Sarah Bosley, "Raising Hearts, Minds and Money: Focus on a New Sales Pitch for British Higher Education," Guardian (UK), May 13, 1986.

42. Douglas Trainer, "Are Tuition Fees a Necessary Evil?" Guardian (UK), December 3, 1996, Education, 2. 
43. Simon Jenkins, "Dons Must Do or Die," Guardian (UK), January 31, 1996; "Higher Education Tuition Fees," Hansard, February 21, 1996, http:/ / hansard .millbanksystems.com/commons/1996/feb/21/higher-education-tuition-fees.

44. Amelia Gentleman, "Students Walk Out in Fees Protest," Guardian (UK), March 5, 1998, 4.

45. Steve Smith, speech to Universities UK on the funding debate, November 25, 2010, http://www.universitiesuk.ac.uk/Newsroom/Speeches/Pages/Professor SteveSmith'sspeechforUUKfundingdebate.aspx.

46. Laura Carlsen, "An Uprising Against the Inevitable," in Subcomandante Insurgente Marcos, The Speed of Dreams: Selected Writings, 2001-2007, ed. Canek PeñaVargas and Greg Ruggiero (San Francisco, 2007), 14.

47. The notions of "critical" and "experimental" attitude are both from Foucault. For Foucault's explanation of the first, see "What Is Critique?" in Michel Foucault, Politics of Truth (Cambridge, 2007). For a discussion of the second, see James Tully, "To Think and Act Differently: Foucault's Four Reciprocal Objections to Habermas' Theory," in Samantha Ashenden and David Owen, eds., Foucault Contra Habermas (London, 1999), 90-142.

48. On "spaces of points of view," see Pierre Bourdieu et al., The Weight of the World: Social Suffering in Contemporary Society (Cambridge, 1999).

49. Simon Critchley, Infinitely Demanding: Ethics of Commitment, Politics of Resistance (London, 2007), 131.

50. James Tully, "Political Philosophy as Critical Activity," Political Theory 30, no. 4 (2002): 546.

51. James Marshall, "Michel Foucault: Liberation, Freedom, Education," Educational Philosophy and Theory 34, no. 4 (2002): 417.

52. Peck, Theodore, and Brenner, "Postneoliberalism and Its Malcontents," 106-11.

53. Tully, "Political Philosophy."

54. Rosalind Gill, "Secrets, Silence and Toxic Shame in the Neoliberal University," in Secrecy and Silence in the Research Process: Feminist Reflections, ed. Róisín RyanFlood and Rosalind Gill (London, 2010).

55. David Nonini, "Thinking About Neoliberalism as if Specificity Mattered," Focaal_European Journal of Anthropology 51 (2008): 152.

56. Tully, "Political Philosophy," 540.

57. "Cambridge Dons Hold Silent Protest," Guardian (UK), January 17, 2006, http:// www.guardian.co.uk/education/2011/jan/17/cambridge-university-dons -protest; "What Is the Campaign for Social Science?" Campaign for Social Science, the Academy of Social Sciences, http://www.campaignforsocialscience.org.uk/ about-CfSS; British Sociological Association, "Statement on Sociology, the BSA and the Cuts," http://sociologyandthecuts.files.wordpress.com/2010/11/statement _on_sociology_the_bsa_and_he_cuts4.pdf.

58. Tully, "Political Philosophy," 540.

59. The universities were London Metropolitan, Sussex, and Middlesex.

60. Elly Badcock, "SOAS: School of Activism Studies," in Clare Solomon and Tania Palmieri, eds., Springtime: The New Student Rebellions (London, 2011), 67.

61. For a rough national map of the occupations, see ibid., 60.

62. Tully, "Political Philosophy," 540.

63. Nineteensixtyseven, "The Occupations in Perspective," The Great Unrest, December 20, 2010, http://thegreatunrest.wordpress.com/2010/12/20/889/. 
64. Brown, "Neoliberalism and the End of Liberal Democracy," 53.

65. For more on these "faces of resistance," see R. Shahjahan, "Engaging the "Faces of Resistance' and Social Change from Decolonizing Perspectives: Toward Transforming Neoliberal Higher Education," Journal of Curriculum Theorizing, forthcoming.

66. Pete Murray, "Workers and Students-Unite and Fight!" Workers United, December 5, 2010, http://the-workers-united.blogspot.com/2010/12/guest-post-workers-and -students-unite.html.

67. Nineteensixtyseven, "The Occupations."

68. Nikolas Kompridis, Critique and Disclosure: Critical Theory Between Past and Future (Cambridge, MA, 2006), 182.

69. Peter Hallward, "A New Strategy Is Needed for a Brutal New Era," Times Higher Education, December 13, 2010, http://www.timeshighereducation.co.uk/story .asp? storycode $=414573$.

70. Wendy Brown et al., "Learning to Love Again, An Interview with Wendy Brown," Contretemps 6 (January 2006): 41, http://sydney.edu.au/contretemps/6January 2006/brown.pdf.

71. Tully, "Political Philosophy," 540.

72. Motto posted on the Really Open University blog, http://reallyopenuniversity .wordpress.com.

73. Jo Casserly, "The Art of Occupation," in Solomon and Palmieri, Springtime, 71.

74. Stevphen Shukaitis and David Graeber, introduction to Constituent Imagination: Militant Investigations/Collective Theorization (Oakland, 2007), 31.

75. For the first theorization see The Inoperative Committee, Preoccupied: The Logic of Occupation (New York, 2009), http://zinelibrary.info/files/preoccupied -imposed.pdf; for the second, see Paolo Plotegher, "London: Beauty, Anger, Joy," UniCommon, February 6, 2011, http://www.unicommon.org/index.php ?option=com_content\&view=article\&id=2501:paolo-plotegher\&catid $=132$ :book-bloc\&Itemid=324.

76. See, e.g., papers under the heading "Occupation of the Political" on the Really Open University blog, http:/ / reallyopenuniversity.wordpress.com/; and James Mills, "Saving the EMA Cuts Protest from the 'Saints," Guardian (UK), January 18, 2011, http://www.guardian.co.uk/commentisfree/2011/jan/18/ema-protest -education-maintenance-allowance.

77. J. K. Gibson-Graham, A Postcapitalist Politics (Minneapolis, 2006), xix.

78. John Jordon cited in ibid.

79. Ian Pears, "After Browne," London Review of Books, March 11, 2011.

80. Clare Solomon, "We Felt Liberated," in Solomon and Palmieri, Springtime, 16.

81. Susan Matthews, "Albion Rose," in ibid., 32.

82. Michel Foucault, "What Is Enlightenment?" in Paul Rabinow, ed., The Foucault Reader (Harmondsworth, 1984), 45.

83. See Dr. Jacques Valentin, "The University for Strategic Optimism and the Spatio-Political Performative,” Scribd, http://www.scribd.com/doc/45743999/ The-Spatio-Political-Performative.

84. Brown, "Learning to Love," 41.

85. Gesa Helms, Marina Vishmidt, and Lauren Berlant, "Affect and the Politics of Austerity: An Interview Exchange with Lauren Berlant," Variant 39/40 (2010): 5.

86. Stuart Stone, "Protests Prove Academic as Government Wins Fees Vote," Founder, January 21, 2011. 
87. Herbert Marcuse, "Philosophy and Critical Theory," in Critical Theory and Society, ed. Stephen Eric Bronner and Douglas Kellner (New York, 1989), 66.

88. Tully, "To Think and Act Differently," 98.

89. Badiou, "The Communist Hypothesis."

90. Bertie Russell and Keir Milburn, "From the Defence of the Present to the Control of the Future," Shift Magazine 11, http://shiftmag.co.uk/?p=398. 